\title{
Potential of Alnus acuminata based agroforestry for carbon sequestration and other ecosystem services in Rwanda
}

\author{
Athanase R. Cyamweshi $(\mathbb{D} \cdot$ Shem Kuyah $\cdot$ Athanase Mukuralinda \\ Catherine W. Muthuri
}

Received: 16 June 2020/Accepted: 25 March 2021/Published online: 18 May 2021

(C) The Author(s) 2021

\begin{abstract}
Alnus acuminata Kunth. (alnus) is widely used in agroforestry systems across the globe and is believed to provide multiple ecosystem services; however, evidence is lacking in agroforestry literature to support the perceived benefits, particularly in Rwanda. To understand carbon sequestration potential and other benefits of alnus, a household survey, tree inventory and destructive sampling were conducted in north-western Rwanda. Over $75 \%$ of the respondents had alnus trees in their farms. The trees provide stakes for climbing beans, firewood and timber. They also improve soil fertility and control soil erosion. Farmers had between 130 and 161 alnus trees per hectare with an average height of $7.7 \pm 0.59 \mathrm{~m}$ and diameter at breast height of $16.3 \pm 1.39 \mathrm{~cm}$. The largest biomass proportion was found in stems $(70.5 \%)$ while branches
\end{abstract}

A. R. Cyamweshi $(\bowtie) \cdot$ S. Kuyah

Department of Botany, Jomo Kenyatta University of Agriculture and Technology (JKUAT),

P.O. Box 62000-00200, Nairobi, Kenya

e-mail: rusacyamweshi@gmail.com

\section{A. R. Cyamweshi}

Rwanda Agriculture and Animal Resources Development Board (RAB), P.O. Box 516, Kigali, Rwanda

\section{A. R. Cyamweshi · A. Mukuralinda}

World Agroforestry (ICRAF), Rwanda Country Office,

RAB Head Quarter, P.O. Box 5016, Kigali, Rwanda

C. W. Muthuri

World Agroforestry (ICRAF), UN Avenue, Gigiri,

P.O. Box 30677-00100, Nairobi, Kenya and leaves stock about 16.5 and $13 \%$ of the total biomass, respectively. At farm level, aboveground biomass of alnus trees was estimated to be $27.2 \pm 0.7 \mathrm{Mg} \mathrm{ha}^{-1}$ representing 13.6 Mg of carbon (C) per hectare. Biomass carbon increased with tree size, from $7.1 \pm 0.2 \mathrm{Mg} \mathrm{C}^{-1}$ in 3 years old trees to $34.4 \pm 2.2 \mathrm{Mg} \mathrm{C} \mathrm{ha}^{-1}$ in 10 years old trees. The converse was observed with elevation; biomass carbon decreased with increasing elevation from $21.4 \pm 1.29 \mathrm{Mg} \mathrm{C} \mathrm{ha}^{-1}$ at low (2011-2110 m) to $9.6 \pm 0.75 \mathrm{Mg} \mathrm{C} \mathrm{ha}{ }^{-1}$ in the high elevation (>2510 m). In conclusion, alnus agroforestry significantly contributes to carbon sequestration, although the magnitude of these benefits varies with tree age and elevation. Planting alnus trees on farms can meet local needs for stakes for climbing beans, wood and soil fertility improvement, as well as the global need for regulation of climate change.

Keywords Aboveground biomass - Agroforestry · Carbon stock · Firewood - Stakes · Soil fertility

\section{Introduction}

Concerns about increasing atmospheric greenhouse gases have encouraged efforts to determine the contribution of different land uses to climate change mitigation through carbon storage. Most of the studies have evaluated the amount of carbon stored in forests 
or that can be released to the atmosphere when forests are cleared, and only few studies have so far considered the role of trees in agricultural landscapes. Constraints cited include limited information regarding the extent of agricultural landscapes with trees (Zomer et al. 2016) and inadequate methods for quantifying biomass in these landscapes (Kuyah et al. 2012). In the latter, the main constraints are lack of standardized methods and heterogeneity of smallholder farms that limit the application of wellestablished forest-based methods (Kuyah et al. 2013). Allometric equations developed for tree species and perennial crops found in agroforestry systems has allowed estimation of biomass and carbon stored in various agroforestry systems, such as scattered trees on farmland (Gebrewahid et al. 2018), rangelands (Feyisa et al. 2018), miombo woodlands (Kuyah et al. 2014) and coffee agroforestry systems (Negash et al. 2013; Tumwebaze et al. 2013). However, there are no allometric equations developed specifically for estimating biomass of trees in agricultural landscapes in Rwanda, making it difficult to determine the contribution of Rwandan agroforestry systems to climate change mitigation.

Agroforestry practices mitigate climate change while contributing to livelihoods of smallholder farmers (Reppin et al. 2019). Reviews estimate that smallholder agroforestry systems in Africa could potentially sequester between 1 and $18 \mathrm{Mg} \mathrm{C}^{-1}$ in aboveground biomass (Montagnini and Nair 2004). Even though these estimates do not consider potential emissions associated with management of agroforestry systems or disturbance, they are within ranges (4.07 and $17 \mathrm{Mg} \mathrm{C} \mathrm{ha}^{-1}$ ) reported by studies evaluating carbon storage of farms in east Africa (Henry et al. 2009; Reppin et al. 2019). The potential of agroforestry to sequester carbon, however, varies depending on climatic conditions, age and management of trees in the landscape and the method used to quantify biomass (Montagnini and Nair 2004). The type of tree species has been shown to have the most impact on carbon storage as it limits the maximum amount of carbon that can be stored under favorable conditions (Kuyah et al. 2014).

Alnus is among trees that have been recommended for agroforestry in the tropics (Russo 1990; Okorio et al. 1994). In Rwanda, alnus has been widely promoted under climate change mitigation and adaptation programs (Byamukama et al. 2011;
Mukuralinda et al. 2016). The tree is found in most household farms in northern and western Rwanda, where it is planted on terraces, as contour hedgerows and in small farm woodlots (Mukuralinda et al. 2016). It also occurs as plantations on degraded landscapes, as trees scattered on crop fields and in homegardens around the homestead (Ndayambaje et al. 2012, 2013).

The potential of alnus for carbon sequestration is high, owing to its fast-growing nature (Rytter and Rytter 2016). However, no study has specifically assessed carbon sequestration potential of alnus under agroforestry management in Rwanda or East Africa. Available studies on the species focused on standing volume for purposes of estimating wood fuel in Rwanda (Ndayambaje et al. 2013), growth and leafing phenology in semiarid (Thika and Naro Moru) areas in Kenya (Muthuri et al. 2004, 2005) and firewood production in Uganda (Siriri et al. 2013). The influence of management on carbon storage potential of alnus is also not known. Generally, agroforestry management influences biomass of trees due to competition with crops and management practices aimed at increasing crop productivity (Nicodemo et al. 2016). Practices such as pollarding and pruning are used to regulate the degree of competition with adjacent crops, and to provide firewood and stakes. Pruning changes the allometry of trees and the partitioning of biomass among components of the tree (Kuyah et al. 2012). In addition, changes in leafing phenology (being semi-deciduous to deciduous in some areas) affects assimilation and water use efficiency in these trees (Muthuri et al. 2009) and hence growth and biomass. It is therefore important to estimate the distribution and biomass carbon of alnus in smallholder systems in Rwanda.

Agroforestry features prominently in Rwanda's national policies on land use, climate change, agriculture and forestry (Ministry of Environment 2018) having been identified as one of the key approaches for increasing agricultural productivity while harnessing ecosystem services provided by trees (Mukuralinda et al. 2016). These policies embed agroforestry as part of land management on hills, given its contribution to soil protection and encourage farmers to grow and manage trees on farms in order to meet the increasing demands of tree products (Iiyama et al. 2018). Planting trees on farms is also encouraged by government agencies, community-based and international organizations working on food security, land restoration and 
climate change. However, lack of reliable estimates of the distribution and carbon density of dominant tree species on farmland limits our ability to project agroforestry's potential for climate change mitigation. This study aims at assessing the potential of alnusbased agroforestry for carbon sequestration and other ecosystem services in Rwanda. The study addressed following research questions: (1) how is biomass carbon distributed along elevation gradient? (2) How is alnus carbon stock influenced by the size and age of alnus trees in the region? (3) What are the benefits that motivated farmers to plant alnus trees in their farmlands?

\section{Materials and methods}

Study site

The study was conducted in Bugeshi sector located in Rubavu district and Karago sector in Nyabihu district (Fig. 1). Bugeshi sector is located at $1^{\circ} 31^{\prime} 52^{\prime \prime} \mathrm{S}$; $29^{\circ} 21^{\prime} 39^{\prime \prime} \mathrm{E}$ with an elevation of $2319 \mathrm{~m}$ while Karago sector is located at $1^{\circ} 38^{\prime} 49^{\prime \prime} \mathrm{S}$ and $29^{\circ} 30^{\prime} 16^{\prime \prime} \mathrm{E}$ with an elevation of $2415 \mathrm{~m}$. The two sectors receive 900 to $1500 \mathrm{~mm}$ rainfall per annum, with annual temperature varying from 10 to $15{ }^{\circ} \mathrm{C}$ in Bugeshi sector and $16-20{ }^{\circ} \mathrm{C}$ in Karago sector. Although Bugeshi sector is at lower elevation compared to Karago, it has lower temperatures because of its location in the vicinity of Karisimbi volcano (elevation: $4750 \mathrm{~m}$ ) which is known for its cold wind and low temperatures. Soils in Karago and Bugeshi sectors are classified as Alisols and Andosols, respectively (Verdoodt and Van Ranst 2006). In both sectors, the vegetation is dominated by many small plantation forests of Markhamia lutea, Grevillea robusta and Eucalyptus spp. (Habiyaremye et al. 2015). Agriculture is the main economic mainstay in the region, practiced for both subsistence and income generation. Tea, coffee, pyrethrum, vegetables, fruits and flowers are grown for export while potato, beans, maize and wheat are grown for subsistence and local market.

Farm selection, household survey and tree inventory

A household survey was conducted between June and July 2019 from all the seven cells of Bugeshi sector (Buringo, Hehu, Butaka, Mutovu, Kabumba, Rusiza and Nsherima) and three cells in Karago sectors (Kadahenda, Gihirwa and Cyamabuye). The selection

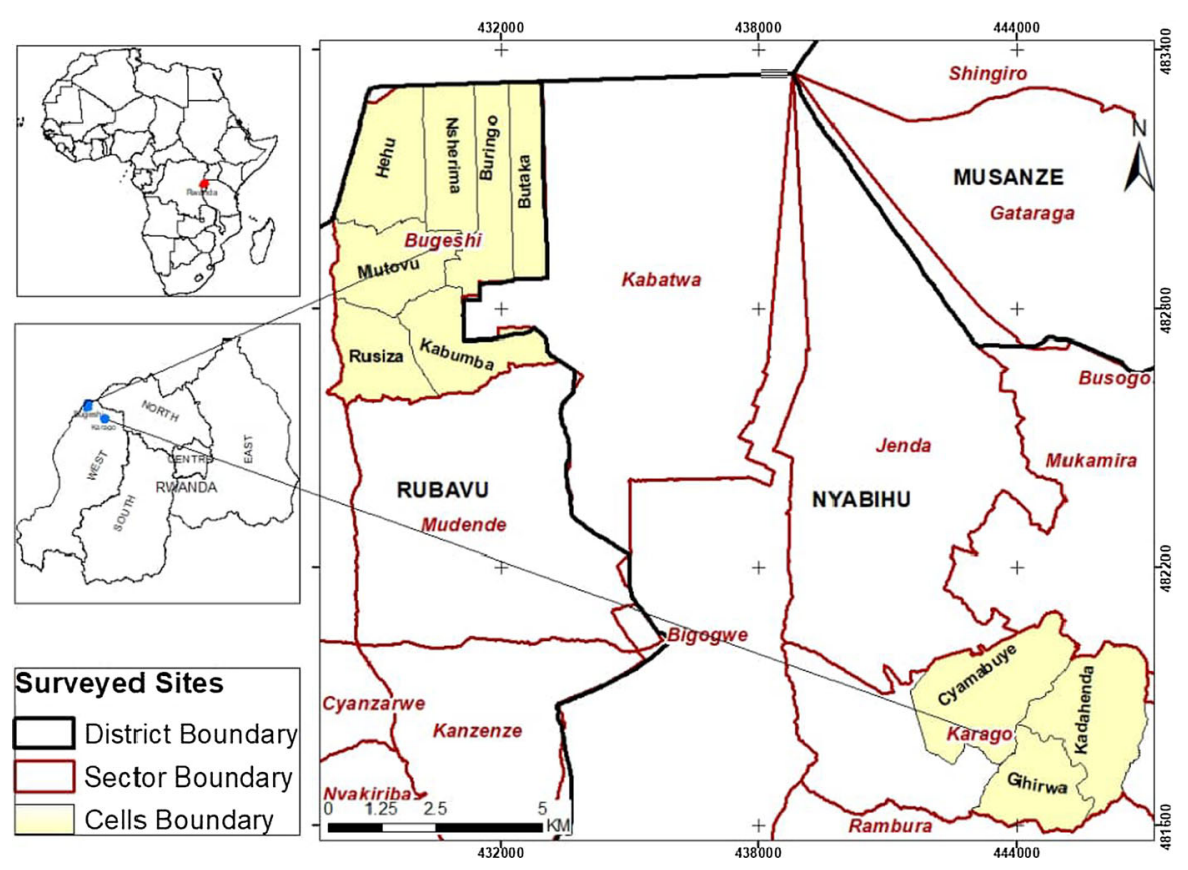

Fig. 1 Location of study sites in north-western Rwanda 
of these cells was purposively done because of the predominance of alnus trees in the farmlands. Farmers were randomly selected for the interview from the list obtained from community leaders in the two sectors. Eighty four farmers from Bugeshi sector and 57 in Karago sector, which ensured at least $10 \%$ of the farmer households were sampled in each sector. The total number of farmers interviewed was 141 . The selected households were interviewed using structured survey questionnaires to elicit information relevant to the study objectives. However, prior to the field interviews, a test survey was conducted with 10 farmers to evaluate the questionnaire, and based on these responses, some minor modifications were made prior to conducting the full survey. The test survey period also permitted standardization of the interview technique for all interviewers.

Tree inventory was only conducted in Rubavu district in the cells of Bugeshi sector. A two-step process was used to collect inventory data. First, all alnus trees within the farm were identified and their diameter at breast height (DBH in $\mathrm{cm}$ ) and height (m) measured using calipers and calibrated pole. DBH was measured over-bark at a height of $1.3 \mathrm{~m}$ above the ground level, with the caliper held tight and horizontal to the stem axis. The diameter was measured twice (crosswise) to account for irregular stems. Tree height was measured from the base of the tree to the tip using a $50 \mathrm{~m}$-measuring tape. In the case of tall trees, height measurement was determined with the help of professional climbers. A professional climber held a calibrated stick so that the zero mark reaches highest tip of the tree. Measurements are then taken from the tip of the tree downward, and summed up to obtain the total height of the tree. This method is recommended where tools such as laser rangefinders or optical dendrometers are not available to make readings at ground level (MacFarlane et al. 2014). Methods outlined by Dietz and Kuyah (2011) were used to maintain consistence in obtaining diameter and height measurements for irregular trees in agricultural landscapes. Crown area was not determined for inventory trees as most of the trees are heavily managed by pruning to provide firewood, stakes for climbing beans and to reduce competition with crops. The niche of the trees within the farm (i.e. whether the tree was planted on boundary, contour hedges, terraces, scattered in crop field or homestead) was documented. The age of the tree was recorded as reported by farmers and varied between 1 and 10 years. Second, the inventory team walked around the farm to identify and document the names of all other tree species found in the farm. The Global Positioning System (GPS) coordinates of each tree measured were recorded and the size of the farm determined by walking around the farm with a handheld GPS device.

\section{Biomass sampling}

A total of 172 trees were harvested from volunteer farms in Karago sector, Nyabihu district. Prior to felling trees, DBH and canopy dimensions were measured. DBH was measured using a caliper while the crown diameter was measured twice using a $50 \mathrm{~m}$ measuring tape: the largest diameter $(l)$ and the diameter perpendicular to it $(w)$. Crown area $\left(\mathrm{m}^{2}\right)$ was calculated using the formula for an ellipse: $\mathrm{ca}=\pi(l / 2) \times(w / 2)$. Trees were cut at the lowest point and the total height determined using $50 \mathrm{~m}$ measuring tape. Felled trees were separated into stem, branches and twigs; larger stem and branches were cut into weighable sections. The stem and branches were bundled separately, and the twigs put in a sack and each weighed using a spring balance. Discs measuring $2.5 \mathrm{~cm}$ thick were taken from the base, middle and top of the stem and their fresh weight determined on a $3 \pm 0.01 \mathrm{~kg}$ scale. Subsamples from branches and twigs including leaves were also taken and weighed in the field. Subsamples were oven-dried in the laboratory at $105{ }^{\circ} \mathrm{C}$ (stem discs and branches) and $70{ }^{\circ} \mathrm{C}$ (twigs) to constant weight. Subsample dry weights of the stem, branches and twigs were determined, and the ratio of dry-to-fresh weights used to convert the fresh weights of the components to dry weights (biomass). Aboveground biomass (AGB) of harvested trees was obtained by adding up the biomass of stem, branches and twigs.

\section{Estimation of biomass carbon}

Data was screened to clean up and to determine outliers and test for normality. Descriptive statistics (means and standard error, SE) for dendrometric variables, biomass and carbon stock were calculated for trees inventoried on farms and harvested trees. Stem diameter was converted to cross-sectional area at breast height to obtain basal area of trees (Torres and Lovett 2013): 
$B A\left(\mathrm{~m}^{2}\right)=\pi * \frac{D B H(\mathrm{~cm})^{2}}{4}$

where BA is the basal area usually expressed in $\mathrm{m}^{2}$; $\pi=3.14 ; \mathrm{DBH}=$ diameter at breast height and is measured in $\mathrm{cm}$. By converting the $\mathrm{cm}^{2}$ to $\mathrm{m}^{2}$ the formula of the basal area becomes:

$B A=\pi * \frac{D B H^{2}}{40000} \mathrm{~m}^{2} \mathrm{ha}^{-1}$

Allometric equations developed for tropical moist forest (Brown 1997) was used to estimate aboveground biomass (AGB) of inventory trees:

$\mathrm{AGB}=\exp [(-2.134+2.530 * \mathrm{LN}(\mathrm{DBH})]$

where $\mathrm{LN}$ is natural logarithm. This equation was selected since there were no suitable species-specific allometric equations for alnus in literature. The equation (power-law model) was considered most appropriate as it includes DBH alone as the predictor variable. Belowground biomass was calculated as a fraction (26\%) of aboveground biomass (Mokany et al. 2006). Total biomass was obtained as the sum of above- and below-ground biomass. Carbon stored in the trees was calculated by multiplying the sum of the total biomass with a carbon fraction of 0.5 (Smith et al. 2014). The amount of $\mathrm{CO}_{2}$ sequestered in aboveground biomass was estimated by multiplying the weight of carbon in the trees by the ratio of $\mathrm{CO}_{2}$ to $\mathrm{C}$ $(44 / 12=3.67)$. The mean annual carbon increment was estimated by dividing the amount of carbon sequestered by the age of the tree. Significant difference means were separated using Fishers protected Least of significant test (LSD) at $p=0.05$. All statistical analyses were done in $\mathrm{R}$ software version 3.5.1 (Team 2018).

\section{Results}

Uses and benefits of alnus in Rwanda

The results revealed a limited variety of tree species on farms in the study sites. More than $78 \%$ of the respondents reported alnus as the most abundant tree species on their farms, followed by Acacia angustissima (6\%), Erythrina abyssinica (4.9\%) and Vernonia amygdalina $(2.7 \%)$. Other tree and shrub species occasionally mentioned were Discopodium penninervium, Calliandra calothyrsus, Tetradenia riparia, G. robusta, Eucalyptus spp. and Persea americana (avocado).

The majority of farmers $(81.5 \%)$ practiced treecrop integration while a few of them $(16.4 \%)$ practiced tree-crop-livestock integration. Only $1.4 \%$ of the farmers planted trees alone as woodlots. Trees in the farms surveyed were mainly planted as contour hedgerow $(45 \%)$ or scattered within the farm (32.4\%). Majority of the households (82\%) own small pieces of lands of about 0.3 ha. Farmers listed 11 major benefits derived from agroforestry trees (Fig. 2). When asked about the purpose of trees on their farms, respondents mentioned provision of stake for climbing beans, soil erosion control, soil fertility improvement, provision of timber, firewood, poles and fodder (Fig. 2).

Alnus tree inventory for biomass estimates

A total of 1767 trees were measured over an area of 13 ha covering 84 farms with an elevation gradient of 2011 to $2634 \mathrm{~m}$ above sea level. Descriptive statistics of the variables from the inventory are summarized in Table 1. The number of alnus trees per farm ranged from 10 to 40 while tree density was between 130 and 161 individuals per hectare. Majority of the trees were of medium age, planted between 2009 and 2018 . Across the landscape, the DBH of the trees inventoried ranged between 3.5 to $30.7 \mathrm{~cm}$, while the tree height ranged between 3.3 and $15.2 \mathrm{~m}$. When the locations were compared, Kabumba cell had significantly larger $(22.2 \pm 0.4 \mathrm{~cm})$ and taller trees $(9.9 \pm 0.22 \mathrm{~m})$ compared to other cells $(p<0.001)$. However, higher tree density was found in Rusiza cell. Basal area varied across the locations, ranging from 1.9 to $6.4 \mathrm{~m}^{2} \mathrm{ha}^{-1}$ with a landscape level mean of $3.6 \mathrm{~m}^{2} \mathrm{ha}^{-1}$. Aboveground biomass of alnus trees found in farms ranged between 11.8 and $53.6 \mathrm{Mg} \mathrm{ha}^{-1}$ (mean of $27.2 \mathrm{Mg} \mathrm{ha}^{-1}$ ). This represents a mean annual increment in aboveground biomass carbon stock of $2.9 \mathrm{Mg}$ $\mathrm{C} \mathrm{ha}^{-1}$ year $^{-1}$ and belowground biomass of $7.1 \mathrm{Mg} \mathrm{ha}^{-1}$. The total biomass (above- and belowground) on farms with alnus was estimated at $34.3 \mathrm{Mg} \mathrm{ha}^{-1}$ representing the carbon stock of 17.1 $\mathrm{Mg} \mathrm{C}^{-1}$ or $62.9 \mathrm{Mg} \mathrm{CO}_{2} \mathrm{eq} \mathrm{ha}^{-1}$.

The mean annual increment (MAI) in carbon stock was lower in young trees and increased with the age of trees. For example, the MAI in carbon stock averaged 


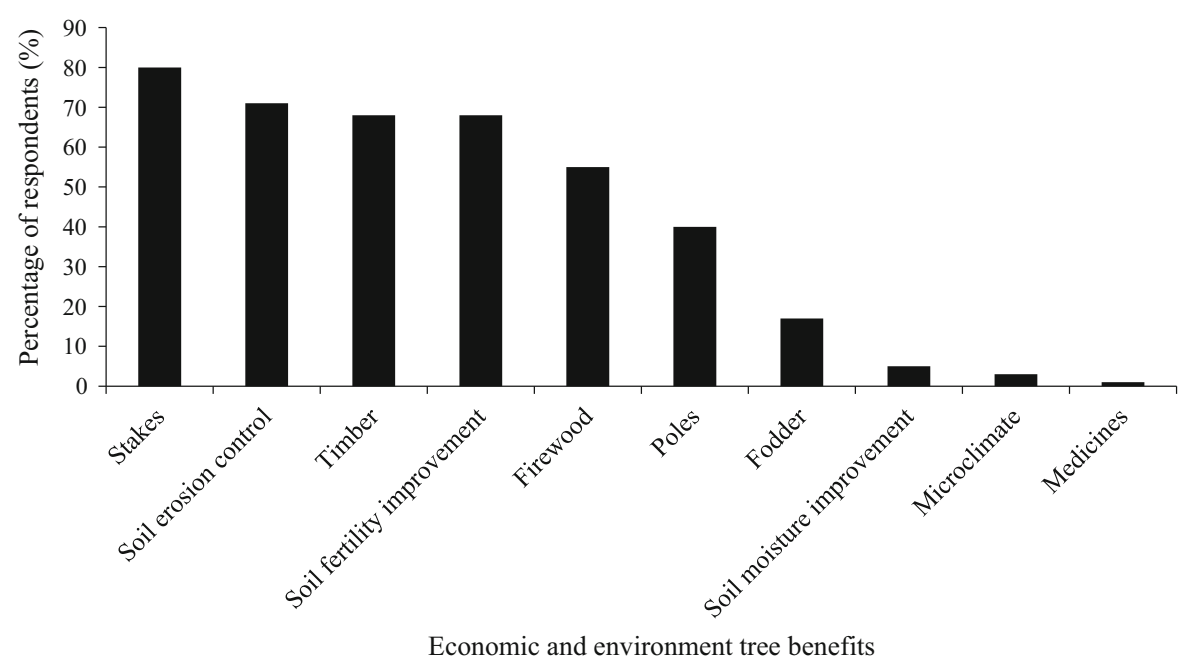

Fig. 2 Uses and benefits that farmers derive from agroforestry trees in Rwanda

Table 1 Descriptive statistics of the variables from alnus tree inventory. Errors are given as standard errors $( \pm$ SE) of means

\begin{tabular}{|c|c|c|c|c|c|c|c|c|}
\hline Location & $\begin{array}{l}\text { Number of } \\
\text { farms }\end{array}$ & $\begin{array}{l}\text { Farm size } \\
\text { (ha) }\end{array}$ & $\begin{array}{l}\text { Stems } \\
\left(\mathrm{ha}^{-1}\right)\end{array}$ & $\begin{array}{l}\text { Age of tree } \\
\text { (years) }\end{array}$ & $\begin{array}{l}\text { Tree height } \\
\text { (m) }\end{array}$ & DBH (cm) & $\begin{array}{l}\text { BA }\left(\mathrm{m}^{2}\right. \\
\left.\mathrm{ha}^{-1}\right)\end{array}$ & $\begin{array}{l}\text { AGB (Mg } \\
\left.\mathrm{ha}^{-1}\right)\end{array}$ \\
\hline Buringo & 12 & $0.17 \pm 0.002$ & $133.9 \pm 0.9$ & $3 \pm 0$ & $7.3 \pm 0.12$ & $12.9 \pm 0.3$ & $2 \pm 0.12$ & $13.4 \pm 1.1$ \\
\hline Butaka & 11 & $0.17 \pm 0.002$ & $140.9 \pm 1.4$ & $3.2 \pm 0.03$ & $7 \pm 0.13$ & $14.1 \pm 0.3$ & $2.4 \pm 0.08$ & $15.5 \pm 0.7$ \\
\hline Hehu & 12 & $0.2 \pm 0.002$ & $131.5 \pm 1.6$ & $3.7 \pm 0.05$ & $6.9 \pm 0.09$ & $14.2 \pm 0.2$ & $2.2 \pm 0.07$ & $14.2 \pm 0.5$ \\
\hline Kabumba & 14 & $0.17 \pm 0.001$ & $151.5 \pm 2.6$ & $7 \pm 0.15$ & $9.9 \pm 0.22$ & $22.2 \pm 0.4$ & $6.4 \pm 0.24$ & $53.6 \pm 2.4$ \\
\hline Mutovu & 13 & $0.12 \pm 0.002$ & $159.4 \pm 1.5$ & $4.5 \pm 0.13$ & $8.3 \pm 0.22$ & $18 \pm 0.5$ & $5 \pm 0.27$ & $40.1 \pm 2.7$ \\
\hline Nsherima & 10 & $0.16 \pm 0.003$ & $130.4 \pm 2.0$ & $3.5 \pm 0.06$ & $6.3 \pm 0.11$ & $13.2 \pm 0.3$ & $1.9 \pm 0.07$ & $11.8 \pm 0.5$ \\
\hline Rusiza & 13 & $0.13 \pm 0.003$ & $161 \pm 2.9$ & $4.7 \pm 0.16$ & $7.6 \pm 0.17$ & $18.5 \pm 0.5$ & $4.8 \pm 0.19$ & $37.0 \pm 1.7$ \\
\hline
\end{tabular}

2.4 $\mathrm{Mg} \mathrm{C} \mathrm{ha}{ }^{-1}$ year $^{-1}$ in trees aged between 1 and 5 years, and $4.03 \mathrm{Mg} \mathrm{C}^{-1}$ year $^{-1}$ in trees aged between 5 and 10 years old. The amount of biomass carbon in young trees ( 1 to 5 years) was $9.6 \pm 0.21 \mathrm{Mg} \mathrm{Cha}^{-1}$, and increased to $33.8 \pm 0.06 \mathrm{Mg} \mathrm{Cha}^{-1}$ in trees between 5 and 10 years (Fig. 3). Majority of the trees in the landscape were 3 to 5 years old. There was a negative relationship between aboveground biomass and elevation. Aboveground biomass carbon decreased with increasing elevation from $21.4 \pm 1.29 \mathrm{Mg} \mathrm{C} \mathrm{ha}^{-1}$ at low (2011-2110 m) to $9.6 \pm 0.75 \mathrm{Mg} \mathrm{C}^{-1}$ in the high elevations (>2510 m) (Fig. 4). Similarly, the number of trees per farm increased from 188 trees per farm at low elevations to 444 trees per farm at middle elevations; then decreased (76 trees per farm) at high elevations.

Tree growth and productivity

A total of 172 alnus trees were harvested on farms for evaluation of growth and productivity in the study area (Table 2). The age of the trees was 3 years (39), 4 years (89) and 5 years (44). Trees were generally small to medium size $(\mathrm{DBH}>23 \mathrm{~cm})$ because most of Alnus were planted between 2009 and 2014. Basal diameter ranged between 10 and $25 \mathrm{~cm}$ (mean: $17.9 \mathrm{~cm}$ ) while DBH varied between 7.3 and $22.7 \mathrm{~cm}$ (mean: $14.5 \mathrm{~cm}$ ). The average height of the trees was $10.8 \mathrm{~m}$ with minimum and maximum values 
Fig. 3 Aboveground biomass (AGB) carbon stock and mean annual increment (MAI) in carbon for alnus trees of different ages in study sites. $\mathrm{n}$ represents the number of trees in each age group
Fig. 4 Amount of carbon stored in alnus trees and mean annual increment (MAI) across elevation gradient (2011-2510 m) in the study sites. $n$ represents the number of trees

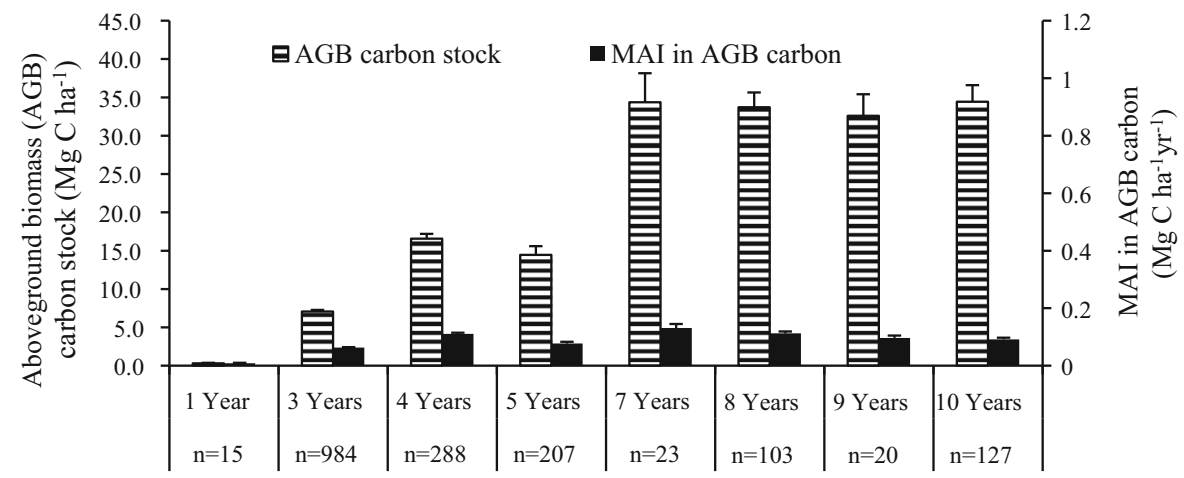

Tree age (years)

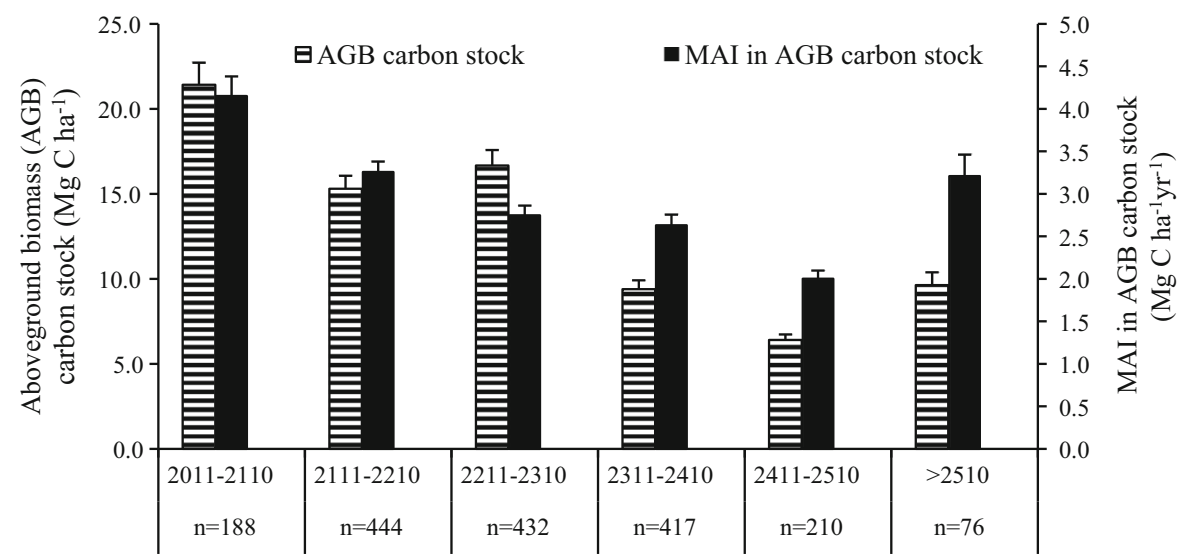

Altitude range (m)

\begin{tabular}{|c|c|c|c|}
\hline Measured parameters & Min & Max & Mean $\pm \mathrm{SE}$ \\
\hline Basal diameter $(\mathrm{m})$ & 10 & 25 & $17.9 \pm 0.4$ \\
\hline Diameter at breast height $(\mathrm{cm})$ & 7.3 & 22.7 & $14.5 \pm 0.3$ \\
\hline Total height (m) & 6.3 & 14.2 & $10.8 \pm 0.1$ \\
\hline Crown area $\left(\mathrm{m}^{2}\right)$ & 5.4 & 35.2 & $20.4 \pm 0.4$ \\
\hline Stem biomass $\left(\mathrm{kg}_{\text {tree }}{ }^{-1}\right)$ & 15.0 & 93.7 & $54.9 \pm 1.3$ \\
\hline Branch biomass $\left(\mathrm{kg}\right.$ tree $\left.^{-1}\right)$ & 2.5 & 25.9 & $12.9 \pm 0.5$ \\
\hline Leaf biomass $\left(\mathrm{kg}_{\text {tree }}{ }^{-1}\right)$ & 2.6 & 30.7 & $10.5 \pm 0.4$ \\
\hline Aboveground biomass $\left(\mathrm{kg}\right.$ tree $\left.{ }^{-1}\right)$ & 35.7 & 119.9 & $78.3 \pm 1.5$ \\
\hline Aboveground biomass carbon $\left(\mathrm{kg}\right.$ tree $\left.{ }^{-1}\right)$ & 17.8 & 59.9 & $39.2 \pm 0.7$ \\
\hline Aboveground $\mathrm{CO}_{2}$ equivalent $\left(\mathrm{kg}\right.$ tree $\left.{ }^{-1}\right)$ & 65.4 & 219.9 & $143 \pm 2.7$ \\
\hline Carbon sequestration rate $\left(\mathrm{kg}\right.$ tree $^{-1}$ year $\left.^{-1}\right)$ & 13.1 & 73.3 & $36.6 \pm 0.8$ \\
\hline
\end{tabular}

Table 2 Summary statistics of the parameters of harvested alnus trees

Numbers in the three columns represent mean (and standard error) of trees; Min represents the minimum values, Max the maximum values and SE the standard error of means 


\section{Discussion}

Alnus is the dominant tree on farmland in the highlands of north-western Rwanda. This is because alnus is adapted to the climate of the region and attract many farmers due to its multiple benefits (Mukuralinda et al. 2016). Most farmers cited provision of stakes for climbing beans as the leading reason for planting alnus. This is consistent with findings by Uwineza et al. (2019) who reported the need for bean staking materials as a motivation for tree planting in the smallhoder farms in Rwanda. Planting of alnus for timber, poles and firewood is motivated by its fast growing nature compared to the majority of other tree species in the region. Farmers also plant alnus trees for environmental benefits such as soil erosion control and soil fertility improvement. These ecosystem services are linked to farmers' desire for improved crop yields via improvement of soil fertility (Ndoli et al. 2017), water regulation and control of soil erosion (Kuyah et al. 2019). Soil and water conservation benefits from alnus have previously been reported in Kenya (Muthuri et al. 2005) and Uganda (Okorio et al. 1994). The density of alnus trees as found during tree inventory (130-161 trees $\mathrm{ha}^{-1}$ ) is in the range of densities of trees reported on croplands in southern Rwanda and depended largely on the size of the land owned by the farmer and other socioeconomic characteristics such as wealth category (Bucagu 2013).

The rate of biomass accumulation increased with tree size and age. These results are compatible with the metabolic scaling theory which predicts that mass growth rate of a tree should increase continuously with tree size and age (Enquist et al. 2000). Similar findings have been reported by various researchers who found that tree growth increased with increase in tree size, and that large trees fix large amounts of carbon compared to smaller trees (Stephenson et al. 2014; Sheil et al. 2017). However, maintaining alnus trees to an advanced age on farmland may not be an easy task considering farmers' pressure on planted trees to satisfy their needs in tree products such stakes for climbing beans, firewood for cooking, and timber for construction. Based on our informal discussion with farmers during tree inventory, tree products are obtained by branch pruning or tree coppicing. This may positively or negatively affect the amount of carbon sequestered by alnus trees depending on how the management practices are conducted (Yadav et al. 2016). Therefore, attention needs to be focused on improving farmers' knowledge on agroforestry tree management practices to enhance tree growth and biomass productivity. Moreover, alnus being the most abundant tree in the region, there is need to diversify tree species to reduce farmers' pressure on alnus trees and maintain them for long duration on farmlands.

Aboveground biomass carbon decreased with increase in elevation. Since the study area neighbors Karisimbi volcano situated at $4507 \mathrm{~m}$ above sea level, the cold temperatures that prevail as altitude increases may have slowed the growth of alnus trees and thus affecting the rate of biomass accumulation. Tree growth rates and biomass productivity may decline because of reduced air and soil temperatures, shorter growing seasons and the increased exposure to wind in high elevation regions (Coomes and Allen 2007). Similar results have been reported in Kilimanjaro, Tanzania, where tree biomass was higher at intermediate elevations and very lower at higher elevations (Ensslin et al. 2015).

Much of the biomass of alnus was held in the stem. The low biomass in branches and leaves can be attributed to farmer management such as pruning, coppicing and pollarding. Farmers remove branches to reduce light competition between trees and understory crops and as part of harvesting wood for firewood and stakes for climbing beans. In the study area, observations in the field indicated that farmers pruned trees leaving only $30 \%$ of the canopy. These results agree with the findings of Mensah et al. (2016) who reported that when trees grow larger, the contribution of wood biomass to the aboveground biomass increases at the expense of leaf biomass.

Alnus trees on farms in Rwanda hold substantial amount of carbon in aboveground biomass (13.6 $\mathrm{Mg} \mathrm{C} \mathrm{ha}^{-1}$ ). This amount falls within the range of carbon stock of 7 to $28 \mathrm{Mg} \mathrm{C}^{-1}$ reported for agroforestry systems of Sub-Saharan Africa (Unruh et al. 1993). However, the values of carbon stock of alnus trees in our study were lower than those (29 to $53 \mathrm{Mg} \mathrm{C} \mathrm{ha}{ }^{-1}$ ) observed in the humid tropical Africa agrosilvicutural system (Albrecht and Kandji 2003) and in traditional agroforestry systems in the tropics (145 Mg C ha ${ }^{-1}$ ) (Kirby and Potvin 2007). 
Comparing the amount of alnus biomass $\left(78.3 \mathrm{~kg} \mathrm{tree}^{-1} \approx 12.6 \mathrm{Mg} \mathrm{ha}^{-1}\right.$ for a density of about 161 tree $^{-1}$ ) estimated using destructive sampling approach and the biomass amount $\left(\approx 27.2 \mathrm{Mg} \mathrm{ha}^{-1}\right.$ ) estimated using inventory data (indirect method), the difference is high and reveals an important bias associated with the methods of biomass estimation (Sileshi 2014). Therefore, this pleads for the use of existing published equations when attempting to assess carbon sequestration potential of the target species in an agroforestry system (Walker et al. 2013).

\section{Conclusion}

This study investigated the potential of carbon sequestration and other benefits of alnus in the agricultural landscape of the highlands of northwestern Rwanda. Alnus dominates the landscape and is planted along contour hedges or scattered within the farms. The tree is mainly managed for provision of stakes for climbing beans, timber and firewood, soil erosion control and for improving soil fertility. Alnus in the agroforestry system contributed to carbon sequestration but the benefits vary with tree age and elevation. Although old trees sequestered higher amount of carbon than young trees, maintaining alnus trees to an advanced age on farmland may not be an easy task considering the farmers' pressure on planted trees to satisfy their needs in tree products. These are obtained through tree pruning and coppicing which may exert adverse effect on alnus trees depending on how the management practices are conducted. The amount of carbon sequestered was higher in lower elevations than that in higher elevation regions suggesting that variation in elevation can significantly affect alnus carbon stocks on farmland. Attention needs to be focused on improving farmers' knowledge on tree management practices to enhance alnus growth and biomass productivity. Beside, diversification of tree species on farmland may reduce farmers' pressure on alnus trees and at the same time fill the gap in high elevation regions where alnus is not well adapted.

Acknowledgements The authors are grateful to the participating farmers during survey and tree inventory, and offered their trees for destructive sampling. The research was funded by the German Academic Exchange Service (DAAD) (Grant No. 91672913) through the World Agroforestry Centre
(ICRAF) and was implemented as part of the project 'Trees for Food Security' made possible by the Australian Centre for International Agricultural Research (ACIAR). The authors also express their gratitude to the Administration of the Rwanda Standard Board (RSB) for availing their laboratory facilities for drying our tree samples.

Open Access This article is licensed under a Creative Commons Attribution 4.0 International License, which permits use, sharing, adaptation, distribution and reproduction in any medium or format, as long as you give appropriate credit to the original author(s) and the source, provide a link to the Creative Commons licence, and indicate if changes were made. The images or other third party material in this article are included in the article's Creative Commons licence, unless indicated otherwise in a credit line to the material. If material is not included in the article's Creative Commons licence and your intended use is not permitted by statutory regulation or exceeds the permitted use, you will need to obtain permission directly from the copyright holder. To view a copy of this licence, visit http://creativecommons.org/licenses/by/4.0/.

\section{References}

Albrecht A, Kandji ST (2003) Carbon sequestration in tropical agroforestry systems. Agric Ecosyst Environ 99:15-27. https://doi.org/10.1016/S0167-8809(03)00138-5

Brown S (1997) Estimating biomass and biomass change of tropical forests: a primer Forest Paper 134. FAO, Rome

Bucagu C (2013) Tailoring agroforestry technologies to the diversity of rwandan smallholder agriculture Charles Bucagu. Wageningen University

Byamukama B, Carey C, Cole M, et al (2011) National strategy on climate change and low carbon development for Rwanda Baseline Report. Univ Oxford Smith Sch Enterp Environ Hayes House, Oxford, p 110. https://doi.org/10. 4210/SSEE.PBS.2011.0002

Coomes DA, Allen RB (2007) Effects of size, competition and altitude on tree growth. J Ecol 95:1084-1097

Dietz J, Kuyah S (2011) Guidelines for establishing regional allometric equations for biomass estimation through destructive sampling. World Agroforestry Center (ICRAF)

Enquist BJ, West GB, Charnov EL, Brown JH (2000) Allometric scaling of production and life-history variation in vascular plants. Nature 408:750

Ensslin A, Rutten G, Pommer U et al (2015) Effects of elevation and land use on the biomass of trees, shrubs and herbs at Mount Kilimanjaro. Ecosphere 6:1-15. https://doi.org/10. 1890/ES14-00492.1

Feyisa K, Beyene S, Megersa B et al (2018) Allometric equations for predicting above-ground biomass of selected woody species to estimate carbon in East African rangelands. Agrofor Syst 92:599-621. https://doi.org/10.1007/ s10457-016-9997-9 
Gebrewahid Y, Gebre-Egziabhier TB, Teka K, Birhane E (2018) Carbon stock potential of scattered trees on farmland along an altitudinal gradient in Tigray, Northern Ethiopia . Ecol Process 7:1-8. https://doi.org/10.1186/s13717-018-0152-6

Habiyaremye JD, Muthuri C, Matiru V et al (2015) Occurrence and abundance of arbuscular mycorrhizal fungi (AMF) in agroforestry systems of Rubavu and Bugesera Districts in Rwanda. Afr J Microbiol Res 9:838-846

Henry M, Tittonell P, Manlay RJ et al (2009) Biodiversity, carbon stocks and sequestration potential in aboveground biomass in smallholder farming systems of western Kenya. Agric Ecosyst Environ 129:238-252. https://doi.org/10. 1016/j.agee.2008.09.006

Iiyama M, Mukuralinda A, Ndayambaje JD et al (2018) Treebased ecosystem approaches (TBEAs) as multi-functional land management strategies-evidence from Rwanda. Sustainability 10:1360

Kirby KR, Potvin C (2007) Variation in carbon storage among tree species: implications for the management of a smallscale carbon sink project. For Ecol Manag 246:208-221

Kuyah S, Dietz J, Muthuri C et al (2012) Allometric equations for estimating biomass in agricultural landscapes: I. Aboveground biomass. Agric Ecosyst Environ 158:216-224. https://doi.org/10.1016/j.agee.2012.05.011

Kuyah S, Dietz J, Muthuri C et al (2013) Allometry and partitioning of above- and below-ground biomass in farmed eucalyptus species dominant in Western Kenyan agricultural landscapes. Biomass Bioenergy 55:276-284. https:// doi.org/10.1016/j.biombioe.2013.02.011

Kuyah S, Sileshi GW, Njoloma J et al (2014) Estimating aboveground tree biomass in three different miombo woodlands and associated land use systems in Malawi. Biomass Bioenergy 66:214-222. https://doi.org/10.1016/j. biombioe.2014.02.005

Kuyah S, Whitney CW, Jonsson M et al (2019) Agroforestry delivers a win-win solution for ecosystem services in subSaharan Africa. A meta-analysis. Agron Sustain Dev 39:18. https://doi.org/10.1007/s13593-019-0589-8

MacFarlane DW, Kuyah S, Mulia R et al (2014) Evaluating a non-destructive method for calibrating tree biomass equations derived from tree branching architecture. Trees 28:807-817

Mensah S, Kakaï RG, Seifert T (2016) Patterns of biomass allocation between foliage and woody structure: the effects of tree size and specific functional traits. Ann For Res 59:49-60. https://doi.org/10.15287/afr.2016.458

Ministry of Environment (2018) Third national communication: report to the united nations framework convention on climate change. Republic of Rwanda, Kigali

Mokany K, Raison RJ, Prokushkin AS (2006) Critical analysis of root: shoot ratios in terrestrial biomes. Glob Chang Biol 12:84-96. https://doi.org/10.1111/j.1365-2486.2005. 001043. $\mathrm{x}$

Montagnini F, Nair PKR (2004) Carbon sequestration: An underexploited environmental benefit of agroforestry systems. Agrofor Syst 61(1-3):281. https://doi.org/10.1023/B: AGFO.0000029005.92691.79

Mukuralinda A, Ndayambaje JD, Iiyama M et al (2016) Taking to scale tree-based systems in Rwanda to enhance food security, restore degraded land, improve resilience to climate change and sequester carbon. PROFOR, Washington, DC

Muthuri CW, Ong CK, Black CR et al (2004) Modelling the effects of leafing phenology on growth and water use by selected agroforestry tree species in semi-arid Kenya. Land Use Water Resour Res 4:1-11

Muthuri CW, Ong CK, Black CR et al (2005) Tree and crop productivity in Grevillea, Alnus and Paulownia-based agroforestry systems in semi-arid Kenya. For Ecol Manag 212:23-39. https://doi.org/10.1016/j.foreco.2005.02.059

Muthuri CW, Ong CK, Craigon J et al (2009) Gas exchange and water use efficiency of trees and maize in agroforestry systems in semi-arid Kenya. Agric Ecosyst Environ 129:497-507. https://doi.org/10.1016/j.agee.2008.11.001

Ndayambaje JD, Heijman WJM, Mohren GMJ (2012) Household determinants of tree planting on farms in rural Rwanda. Small-scale For 11:477-508. https://doi.org/10. 1007/s11842-012-9196-0

Ndayambaje JD, Heijman WJM, Mohren GMJ (2013) Farm woodlots in rural Rwanda: purposes and determinants. Agrofor Syst 87:797-814. https://doi.org/10.1007/s10457013-9597-x

Ndoli A, Baudron F, Schut AGT et al (2017) Disentangling the positive and negative effects of trees on maize performance in smallholdings of Northern Rwanda. Field Crop Res 213:1-11. https://doi.org/10.1016/j.fcr.2017.07.020

Negash M, Starr M, Kanninen M, Berhe L (2013) Allometric equations for estimating aboveground biomass of Coffea arabica L. grown in the Rift Valley escarpment of Ethiopia. Agrofor Syst 87:953-966. https://doi.org/10.1007/ s10457-013-9611-3

Nicodemo MLF, Castiglioni PP, Pezzopane JRM et al (2016) Reducing competition in agroforestry by pruning native trees. Rev Árvore 40:509-518

Okorio J, Byenkya S, Wajja N, Peden D (1994) Comparative performance of seventeen upperstorey tree species associated with crops in the highlands of Uganda. Agrofor Syst 26:185-203. https://doi.org/10.1007/BF00711210

Reppin S, Kuyah S, de Neergaard A et al (2019) Contribution of agroforestry to climate change mitigation and livelihoods in Western Kenya. Agrofor Syst. https://doi.org/10.1007/ s10457-019-00383-7

Russo RO (1990) Evaluating Alnus acuminata as a component in agroforestry systems. Agrofor Syst 10(3):241-252

Rytter L, Rytter R-M (2016) Growth and carbon capture of grey alder (Alnus incana (L.) Moench.) under north European conditions-estimates based on reported research. For Ecol Manag 373:56-65

Sheil D, Eastaugh CS, Vlam M, Zuidema PA, Groenendijk P, van der Sleen P, Vanclay J (2017) Does biomass growth increase in the largest trees? Flaws, fallacies and alternative analyses. Funct Ecol 31(3):568-581

Sileshi GW (2014) A critical review of forest biomass estimation models, common mistakes and corrective measures. For Ecol Manag 329:237-254

Siriri D, Wilson J, Coe R et al (2013) Trees improve water storage and reduce soil evaporation in agroforestry systems on bench terraces in SW Uganda. Agrofor Syst 87:45-58. https://doi.org/10.1007/s10457-012-9520-x

Smith P, Bustamante M, Ahammad H, Clark H, Dong H, Elsiddig EA, Haberl H, Harper R, House J, Jafari M (2014) 
Agriculture, forestry and other land use (AFOLU). In: Climate change 2014: mitigation of climate change. Contribution of Working Group III to the Fifth Assessment Report of the Intergovernmental Panel on Climate Change. Cambridge University Press

Stephenson NL, Das AJ, Condit R et al (2014) Rate of tree carbon accumulation increases continuously with tree size. Nature 507:93-94. https://doi.org/10.1038/nature12914

Team RC (2018) R: a language and environment for statistical computing. R Foundation for Statistical Computing, Vienna

Torres AB, Lovett JC (2013) Using basal area to estimate aboveground carbon stocks in forests: La Primavera Biosphere's Reserve, Mexico. Forestry 86:267-281. https:// doi.org/10.1093/forestry/cps084

Tumwebaze SB, Bevilacqua E, Briggs R, Volk T (2013) Allometric biomass equations for tree species used in agroforestry systems in Uganda. Agrofor Syst 87:781-795. https://doi.org/10.1007/s10457-013-9596-y

Unruh JD, Houghton RA, Lefebvre PA (1993) Carbon storage in agroforestry: an estimate for sub-Saharan Africa. Clim Res 3:39-52

Uwineza MC, Yujun S, Ndekezi A (2019) Farmer's perceptions on importance and role of agroforestry species in Karago,
Rwanda. Int J Sci 5:72-79. https://doi.org/10.18483/ijsci. 1882

Verdoodt A, Van Ranst E (2006) Environmental assessment tools for multi-scale land resources information systems: a case study of Rwanda. Agric Ecosyst Environ 114:170-184

Walker SM, Pearson TRH, Casarim FM, Harris N, Petrova S, Grais A, Swails E, Netzer M, Goslee KM, Brown S (2013) Standard operating procedures for terrestrial carbon measurement: Version 2012. In: Winrock international. www. winrock.org/ecosystems

Yadav RP, Bisht JK, Pandey BM et al (2016) Cutting management versus biomass and carbon stock of oak under high density plantation in Central Himalaya, India. Appl Ecol Environ Res 14:207-214

Zomer RJ, Neufeldt H, Xu J et al (2016) Global tree cover and biomass carbon on agricultural land: the contribution of agroforestry to global and national carbon budgets. Sci Rep. https://doi.org/10.1038/srep29987

Publisher's Note Springer Nature remains neutral with regard to jurisdictional claims in published maps and institutional affiliations. 